\title{
Estimation of Heterosis for Grain Yield and Architectural Traits in Yellow Seeded Maize (Zea mays L.)
}

\author{
Meenakshi Dhoot ${ }^{1^{*}}$, R.B. Dubey ${ }^{1}$, K.D. Ameta ${ }^{2}$, Rupal Dhoot ${ }^{3}$, \\ Ramesh Kumar ${ }^{1}$ and Varun Kumar Badaya ${ }^{1}$
}

\author{
${ }^{1}$ Department of Plant Breeding and Genetics, ${ }^{2}$ Department of Horticulture, Rajasthan College of \\ Agriculture, Maharana Pratap University of Agriculture and Technology, Udaipur-313001, \\ Rajasthan, India \\ ${ }^{3}$ Department of Genetics and Plant Breeding, Navsari Agricultural University, Navsari- \\ 396450, Gujarat, India \\ *Corresponding author
}

\begin{tabular}{|c|c|}
\hline & A B S T R A C T \\
\hline & \multirow{6}{*}{$\begin{array}{l}\text { Tools for yield prediction are requisite to any successful heterosis breeding program. In } \\
\text { this study, heterosis was evaluated in } 10 \times 10 \text { half diallel along with } 3 \text { checks in RBD with } \\
3 \text { replications in maize for grain yield and architectural traits viz., ear length, number of } \\
\text { grain rows per ear, } 100 \text {-grain weight, grain yield per plant and harvest index etc. } \\
\text { Significant positive mid-parent heterosis ranged from } 11.11 \text { to } 27.66 \text { per cent, } 13.51 \text { to } \\
17.95 \text { per cent, } 7.07 \text { to } 47.66 \text { per cent, } 23.93 \text { to } 82.39 \text { per cent and } 8.84 \text { to } 25.18 \text { per cent } \\
\text { for ear length, number of grain rows per ear, } 100 \text {-grain weight, grain yield per plant and } \\
\text { harvest index and respectively. Out of forty five hybrids, two hybrids for ear length, one } \\
\text { hybrid for number of grain rows per ear show positive significant better-parent heterosis. } \\
\text { In case of grain yield per plant positive significant better-parent heterosis was exhibited by } \\
\text { eleven hybrids with maximum magnitude of this heterosis depicted by the hybrid P1 x P2 } \\
\text { (66.03\%). Hybrid P8 x P9 ( } 42.88 \%) \text { exhibited maximum positive significant better-parent } \\
\text { heterosis and hybrid P4 x } 10 \text { ( } 11.94 \%) \text { exhibited maximum positive significant economic } \\
\text { heterosis for } 100 \text {-grain weight. For harvest index, hybrid P1 x P2 (18.57\%) exhibited } \\
\text { maximum positive significant better-parent heterosis and hybrid P6 } \text { x P7 }(14.63 \%) \\
\text { obtained maximum positive significant economic heterosis. This hybrid also shows highest } \\
\text { magnitude of positive significant economic heterosis for grain yield per plant }(41.67 \%) \text {. }\end{array}$} \\
\hline & \\
\hline $\begin{array}{l}\text { Maize, Heterosis, } \\
\text { diallel, Grain yield } \\
\text { and Architectural } \\
\text { traits. }\end{array}$ & \\
\hline Article Info & \\
\hline $\begin{array}{l}\text { Accepted: } \\
\text { 31 June } 2017 \\
\text { Available Online: } \\
\text { 10 July } 2017\end{array}$ & \\
\hline & \\
\hline
\end{tabular}

\section{Introduction}

Maize (Zea mays L.) is an important cereal crop belonging to the tribe Maydeae, of the grass family, Poaceae. It is a versatile crop with wider genetic variability and able to grow successfully throughout the world covering tropical, subtropical and temperate agroclimatic conditions It is used world-wide for feed, food and also serves as a source of basic raw material for a number of industries viz., oil, starch, protein, food, alcoholic beverages, sweeteners, cosmetics, bio- fuels etc. Maize is an extensively investigated crop for heterosis breeding and occupies the pride place in launching the first hybrid breeding programme in the country under auspicious of all India Co-ordinated Maize Improvement Project. The breeding strategy for exploitation of heterosis in maize (Zea mays L.) through the 
cultivation of single cross hybrids is primarily dependent on the development and identification of high per se performing diverse, vigorous and productive inbred lines with good seed quality and their subsequent evaluation for combining ability in cross combinations to identify single crosses with high heterotic effects. The phenomenon of heterosis has provided the most important genetic tool improving yield potential of crop plants. Heterosis breeding is primary based to the identification of parents and their cross combinations capable of producing the highest level of transgressive segregates. The magnitude of heterosis depends on the extent of genetic diversity between parents and helps in choosing the parents for superior $F_{1}$ hybrids.

So, the objective of this paper is to assess heterosis, better-parent heterosis, and economic heterosis, and on the basis of the study, superior inbred lines and hybrids will be identified for grain yield and architectural traits viz., ear length, number of grain rows per ear, 100-grain weight, grain yield per plant and harvest index etc.

\section{Materials and Methods}

The experimental material comprising ten $\mathrm{S}_{6}$ inbred lines were crossed using diallel design during Rabi 2013-2014 and developed 45 half-diallel crosses (reciprocals excluded). These 45 hybrids with 10 parental inbred lines and three economic checks viz., Prakash, PMH-5, HM-8 were evaluated in randomized block design with three replications during Kharif 2014 at the Instructional farm, Rajasthan College of Agriculture, Maharana Pratap University of Agriculture and Technology, Udaipur. Each treatment was grown in single row plot of $4.0 \mathrm{~m}$ row length with row to row and plant to plant spacing of $60 \mathrm{~cm}$. and $25 \mathrm{~cm}$. respectively. Recommended package of practices of zone IV (a) of Rajasthan were used to raise a healthy crop. The data were recorded on grain yield and architectural traits viz., ear length, number of grain rows per ear, 100-grain weight, grain yield per plant and harvest index on ten randomly selected competitive plants (Table 1). Pooled magnitude of heterosis over mid parent (MP) or mid-parent heterosis, better-parent (BP) or better-parent heterosis and economic or standard-check (SC) heterosis were calculated as per economic procedure respectively Shull (1908), Fonseca and Patterson(1968), Briggle (1963).

\section{Results and Discussion}

The mean square due to genotypes, parents, crosses and parents v/s crosses were significant for all the traits, except due to parents $\mathrm{v} / \mathrm{s}$ crosses for ear length, number of grain rows per ear and grain yield per plant. This indicated the existence of appreciable amount of genetic variability in the experimental material of the present investigation (Table 1).

Out of forty five hybrids, eight hybrids depicted positive significant mid-parent heterosis for ear length with range varied from $11.11 \%(\mathrm{P} 2 \times \mathrm{P} 8)$ to $27.66 \%(\mathrm{P} 3 \times \mathrm{P} 8)$; two hybrids viz., P2 x P7 (17.95\%) and P2 x P7 $(13.51 \%)$ for number of grain rows per ear. In case of 100-grain weight, out of forty five hybrids, positive significant mid-parent heterosis was exhibited by twenty six hybrids and ranged from $7.07 \%(\mathrm{P} 1 \times \mathrm{P} 10)$ to 47.66 $\%$ (P8 $x$ P9). The maximum positive significant mid-parent heterosis was depicted by hybrid P8 x P9 (47.66 \%) followed by hybrid P4 x P10 (46.86 \%) for 100-grain weight. For grain yield per plant, out of forty five hybrids, fourteen hybrids exhibited positive significant mid-parent heterosis. It's ranged from $23.93 \%(\mathrm{P} 2 \times \mathrm{P} 7)$ to $82.39 \%$ (P1 x P2). The maximum positive significant mid-parent heterosis was depicted by the hybrid P1 x P2 (82.39 \%) followed by hybrid P1 x P5 (78.78 \%) and hybrid P1 x P8 (66.27 
$\%$ ) for grain yield per plant. Fifteen hybrids expressed positive significant mid-parent heterosis for harvest index with the magnitude ranged from $8.84 \%(\mathrm{P} 2 \times \mathrm{P} 6)$ to $25.18 \%(\mathrm{P} 1$ $\mathrm{x}$ P5). The study of mid-parent (MP) heterosis revealed that number of hybrids depicting positive significant mid-parent heterosis for yield and yield contributing traits ranged from 2 (number of grain rows per ear) to 15 (harvest index). Similar findings for mid parent heterosis for grain yield per plant, 100grain weight, harvest index, number of grains rows per ear were also obtained by Dubey et al., (2009), Amanullah et al., (2011), Silva et al., (2011), Abuali et al., (2012) Avinashe et al., (2013), Gautam et al., (2013), Ali et al., (2014), Khan et al., (2014), Ofori et al., (2015) and Ruswandi et al., (2015) (Tables 2 and 3).

Table.1 Analysis of variance for grain yield and yield contributing characters in maize

\begin{tabular}{|c|c|c|c|c|c|c|}
\hline \multirow{2}{*}{$\begin{array}{l}\text { Source of } \\
\text { variance }\end{array}$} & \multirow{2}{*}{ Df } & \multicolumn{5}{|c|}{ Mean Squares } \\
\hline & & $\begin{array}{l}\text { Ear } \\
\text { length }\end{array}$ & $\begin{array}{l}\text { Number of grain } \\
\text { rows per ear }\end{array}$ & $\begin{array}{l}\text { 100-grain } \\
\text { weight }\end{array}$ & $\begin{array}{l}\text { Grain yield } \\
\text { per plant }\end{array}$ & $\begin{array}{l}\text { Harvest } \\
\text { index }\end{array}$ \\
\hline Replication & 2 & 1.519 & 2.206 & 1.673 & $806.297 *$ & 0.915 \\
\hline Genotype & 54 & $3.7189 * *$ & $2.987 * *$ & $31.441 * *$ & $1881.3 * *$ & $11.9187 * *$ \\
\hline Parent & 9 & $3.715^{* *}$ & $3.615^{* *}$ & $37.128 * *$ & $2184.8 * *$ & $14.356^{* *}$ \\
\hline Crosses & 44 & $3.719 * *$ & $2.909 * *$ & $28.5048^{* *}$ & $1851.45^{* * *}$ & $11.221^{* *}$ \\
\hline $\begin{array}{l}\text { Parent vs. } \\
\text { Crosses }\end{array}$ & 1 & & & & & \\
\hline $\begin{array}{l}\text { Crosses } \\
\text { Error }\end{array}$ & 108 & $\begin{array}{l}3.70647 \\
0.998299\end{array}$ & $\begin{array}{l}0.775758 \\
1.02088\end{array}$ & $\begin{array}{l}109.486 \\
1.52982\end{array}$ & $\begin{array}{l}463.2 / 6 \\
171.217\end{array}$ & $\begin{array}{l}20 . / 084 \\
2.24231\end{array}$ \\
\hline
\end{tabular}

$*$ and $* *$ means Significant at $5 \%$ and $1 \%$ respectively.

Table.2 Per se Performance of inbred lines and checks for ear length $(\mathrm{cm})$, number of grains rows per ear, 100 grain weight $(\mathrm{g})$, grain yield per plant (g) and harvest index (\%) in maize

\begin{tabular}{|c|c|c|c|c|c|c|}
\hline S.No & Genotype & $\begin{array}{l}\text { Ear length } \\
\text { (cm) }\end{array}$ & $\begin{array}{l}\text { Number of } \\
\text { grains } \\
\text { rows per } \\
\text { Ear } \\
\end{array}$ & $\begin{array}{l}100 \text { Grain } \\
\text { weight }(g)\end{array}$ & $\begin{array}{l}\text { Grain } \\
\text { yield per } \\
\text { Plant (g) }\end{array}$ & $\begin{array}{l}\text { Harvest } \\
\text { Index }(\%)\end{array}$ \\
\hline 1 & P1 & 12.83 & 15.33 & 25.88 & 71.67 & 21 \\
\hline 2 & P2 & 13.47 & 13.33 & 26.71 & 87.33 & 23.33 \\
\hline 3 & P3 & 11.53 & 14.67 & 30.57 & 103.33 & 24.33 \\
\hline 4 & P4 & 15.33 & 14.67 & 24.96 & 123.33 & 25.67 \\
\hline 5 & P5 & 14.43 & 12 & 27.82 & 98 & 25.33 \\
\hline 6 & P6 & 15.13 & 14.67 & 33.13 & 106.67 & 25.67 \\
\hline 7 & P7 & 14 & 12.67 & 26.12 & 146.67 & 28.33 \\
\hline 8 & P8 & 13.53 & 12.67 & 21.58 & 66.67 & 24 \\
\hline 9 & P9 & 13.87 & 14 & 23.07 & 143.33 & 28 \\
\hline 10 & P10 & 13.2 & 13.33 & 23.25 & 96.67 & 23.67 \\
\hline 11 & Prakash & 14.33 & 13.33 & 26.91 & 100 & 26.33 \\
\hline 12 & HM-8 & 15.2 & 13.33 & 30.17 & 103.33 & 25.67 \\
\hline 13 & PMH-5 & 15.13 & 14 & 31.63 & 120 & 27.33 \\
\hline
\end{tabular}

PMH-5- Punjab Maize Hybrid-5, HM-8 - Hisar Maize-8 
Table.3 Range of positive significant heterosis over mid-parent (MP), better parent (BP) and standard check (SC) and positive hybrids (in parenthesis) for ear length (cm), number of grains rows per ear, 100 grain weight $(\mathrm{g})$, grain yield per plant $(\mathrm{g})$ and harvest index $(\%)$ in maize

\begin{tabular}{|c|c|c|c|c|c|c|}
\hline \multirow[t]{2}{*}{ Characters } & \multicolumn{3}{|c|}{ Range of Heterosis (\%) } & \multicolumn{3}{|c|}{ Best hybrid on the basis of highest heterosis } \\
\hline & MP & BP & $\mathrm{SC}$ & MP & $\mathrm{BP}$ & $\mathrm{SC}$ \\
\hline $\begin{array}{l}\text { Ear length } \\
\quad(\mathrm{cm})\end{array}$ & $\begin{array}{c}11.11 \% \\
\text { to } 27.66 \\
\%(8)\end{array}$ & $\begin{array}{c}16.36 \% \text { to } \\
18.23 \% \\
\text { (2) }\end{array}$ & - & $\begin{array}{c}\mathrm{P}_{3} \times \mathrm{P}_{8} \\
(96.20 \%)\end{array}$ & $\begin{array}{c}\mathrm{P}_{3} \mathrm{X} \\
\mathrm{P}_{8}(18.23 \%)\end{array}$ & - \\
\hline $\begin{array}{c}\text { Number of } \\
\text { grains rows } \\
\text { per Ear }\end{array}$ & $\begin{array}{c}13.51 \% \\
\text { to } 17.95 \\
\%(2)\end{array}$ & $15.00 \%(1)$ & - & $\begin{array}{c}\mathrm{P}_{2} \times \mathrm{P}_{7} \\
(17.95 \%)\end{array}$ & $\begin{array}{c}\mathrm{P}_{2} \times \mathrm{P}_{7} \\
(15.00 \%)\end{array}$ & - \\
\hline $\begin{array}{l}100 \text { Grain } \\
\text { weight }(\mathrm{g})\end{array}$ & $\begin{array}{c}7.07 \% \text { to } \\
47.66 \% \\
(26)\end{array}$ & $\begin{array}{c}9.32 \%- \\
42.88 \% \\
(14)\end{array}$ & $\begin{array}{l}11.94 \\
\%(1)\end{array}$ & $\begin{array}{c}\mathrm{P}_{8} \times \mathrm{P}_{9} \\
(47.66 \%)\end{array}$ & $\begin{array}{c}\mathrm{P}_{8} \times \mathrm{P}_{9} \\
(42.88 \%)\end{array}$ & $\begin{array}{c}\mathrm{P}_{4} \times \mathrm{P}_{10} \\
(11.94 \%)\end{array}$ \\
\hline $\begin{array}{l}\text { Grain yield } \\
\text { per plant }(\mathrm{g})\end{array}$ & $\begin{array}{c}23.93 \% \\
\text { to } 82.39 \\
\%(14)\end{array}$ & $\begin{array}{c}15.91 \%- \\
66.03 \% \\
(11)\end{array}$ & $\begin{array}{c}20.83 \%- \\
41.67 \% \\
(5)\end{array}$ & $\begin{array}{c}\mathrm{P}_{1} \times \mathrm{P}_{2} \\
(82.39 \%)\end{array}$ & $\begin{array}{c}\mathrm{P}_{1} \times \mathrm{P}_{2} \\
(66.03 \%)\end{array}$ & $\begin{array}{c}\mathrm{P}_{6} \times \mathrm{P}_{7} \\
(41.67 \%)\end{array}$ \\
\hline $\begin{array}{c}\text { Harvest } \\
\text { index }\end{array}$ & $\begin{array}{c}8.84 \% \text { to } \\
25.18 \% \\
(15)\end{array}$ & $\begin{array}{c}10.39 \% \text { to } \\
18.57 \% \\
(8)\end{array}$ & $\begin{array}{c}14.63 \% \\
(1)\end{array}$ & $\begin{array}{c}\mathrm{P}_{1} \times \mathrm{P}_{5} \\
(25.18 \%)\end{array}$ & $\begin{array}{c}\mathrm{P}_{1} \times \mathrm{P}_{2} \\
(18.57 \%)\end{array}$ & $\begin{array}{c}\mathrm{P}_{6} \times \mathrm{P}_{7} \\
(14.63 \%)\end{array}$ \\
\hline
\end{tabular}

Table.4 Superior hybrids identified on the basis of mid-parent (mp), better parent (bp) and standard check heterosis (sc) for grain yield per plant with relationship between 100-Grain weight $(\mathrm{g})$ and Harvest Index $(\%)$ in maize

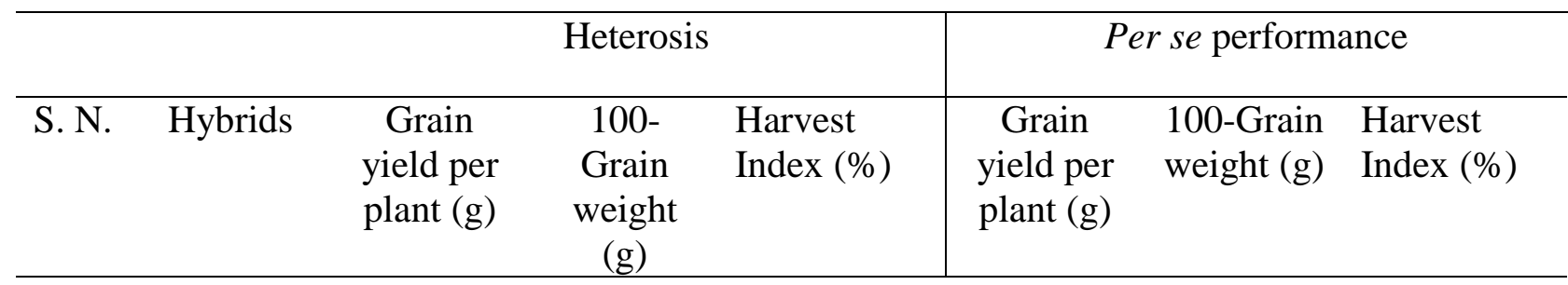

Mid-parent heterosis

$\begin{array}{llllclll}\text { 1. } & \mathrm{P}_{6} \times \mathrm{P}_{7} & 34.21 * * & 9.93 * * & 16.05 * * & 170 & 32.57 & 31.33 \\ \text { 2. } & \mathrm{P}_{1} \times \mathrm{P}_{5} & 78.78 * * & 17.26 * * & 25.18^{* *} & 151.67 & 31.48 & 29 \\ \text { 3. } & \mathrm{P}_{4} \times \mathrm{P}_{6} & 27.54 * * & 10.71 * * & 6.49 & 146.67 & 32.16 & 27.33 \\ \text { 4. } & \mathrm{P}_{1} \times \mathrm{P}_{2} & 82.39 * * & 17.36^{* *} & 24.81 * * & 145 & 30.86 & 27.67 \\ \text { 5. } & \mathrm{P}_{2} \times \mathrm{P}_{7} & 23.93 * * & 10.56 * * & 9.68 * & 145 & 29.2 & 28.33 \\ \text { 6. } & \mathrm{P} 4 \times \mathrm{P} 10 & 12.12 & 46.86 * * & 13.51 * * & 123.33 & 35.4 & 28\end{array}$

Better-parent heterosis

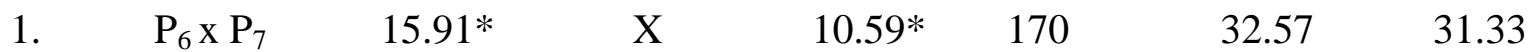


Int.J.Curr.Microbiol.App.Sci (2017) 6(7): 4536-4542

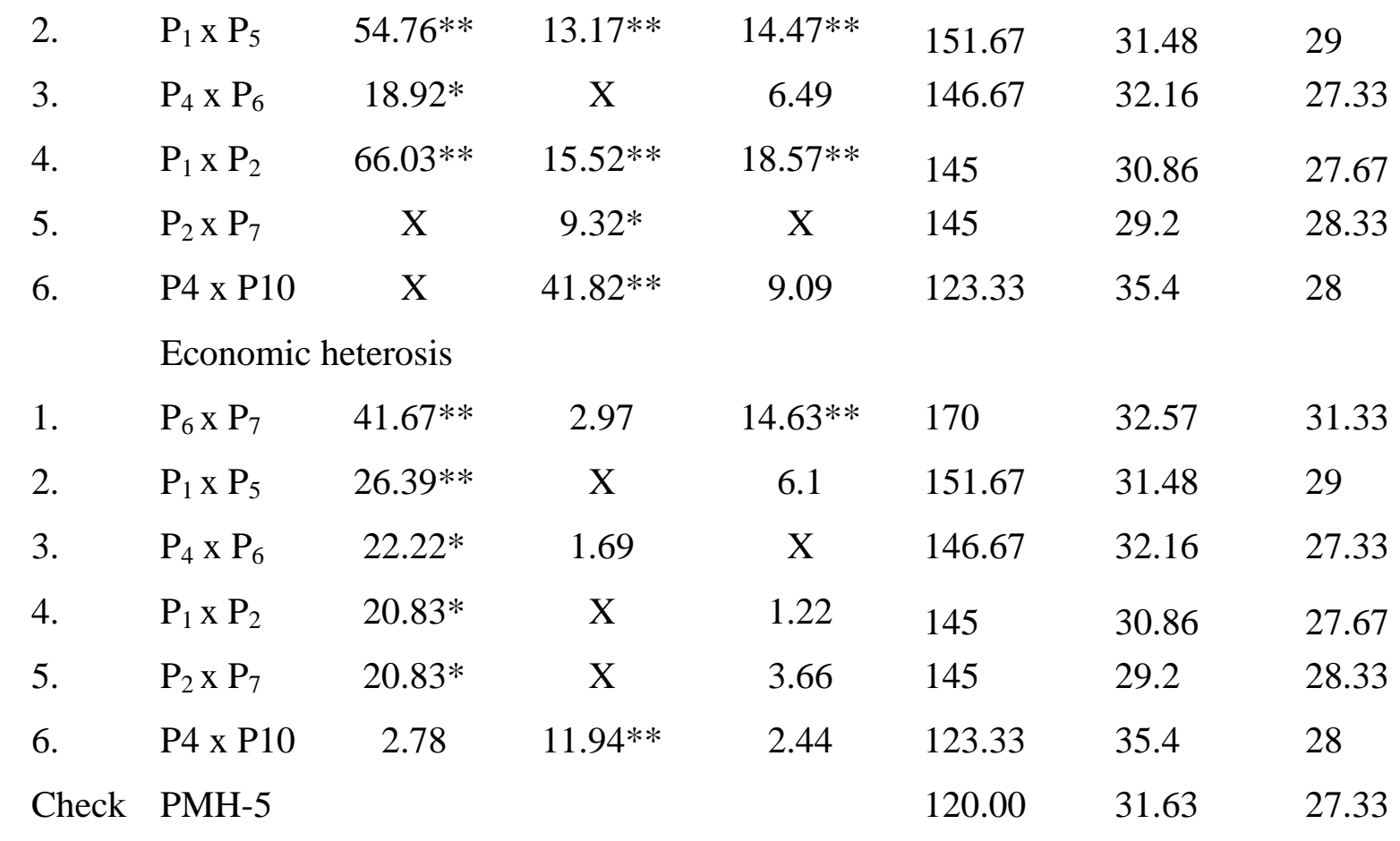

$*$ and ** means Significant at 5\% and $1 \%$ respectively; $\mathrm{X}$ indicate no heterosis or no value

Fourteen hybrids depicted positive significant better-parent heterosis for 100-grain weight while two hybrids for ear length and one hybrid (P2 x P7) for number of grain rows per ear. Better-parent heterosis for grain yield per plant was exhibited by eleven hybrids with maximum magnitude of better-parent heterosis depicted by the hybrid P1 x P2 $(66.03 \%)$. This hybrid also exhibited significant positive better-parent heterosis for harvest index $(80.03 \%)$, whereas the number of hybrids depicting positive significant better-parent heterosis for harvest index was 8.

Heterosis over better parent for grain yield per plant, 100-grain weight was also reported by Appunu et al., (2007), Gissa et al., (2007), Jampatong et al., (2010), Amanullah et al., (2011), Bedhendi et al., (2011), Silva et al., (2011), Raghu et al., (2012), Avinashe et al., (2013), Dhairyashil et al., (2013), Netravarti et al., (2013), Ali et al., (2014) and Khan et al., (2014).
In case of economic heterosis, for grain yield per plant revealed that only five hybrids namely P6 x P7, P1 x P5, P4 x P6, P1 x P2 and $\mathrm{P} 2 \times \mathrm{P} 7$ depicted positive significant economic heterosis for grain yield per plant over the best check PMH-5 (Table 4). Hybrid P4 x P10 exhibited positive significant economic heterosis for 100-grain weight $(11.94 \%)$ over the best check PMH-5. Only one hybrid namely P6 x P7 expressed positive significant economic heterosis for harvest index $(14.63 \%)$ over the best check PMH-5 (Table 4). Reddy et al., (2011), Amiruzzaman et al., (2013), Izhar and Chakraborthy (2013), Netravarti et al., (2013), Kage et al., (2013), Kumar et al., (2014) and Ruswandi et al., (2015) also reported positive significant economic heterosis in maize for grain yield and its contributing traits. None of the hybrid exhibited positive significant economic heterosis for ear length and number of grain rows per ear.

In conclusion, in present study, on the basis of mean value, the inbred line $\mathrm{P}_{7}$ exhibited 
maximum mean value for grain yield per plant (146.67 g/p) and harvest index (28.33\%) while the inbred line $\mathrm{P}_{6}$ exhibited highest mean values for 100- grain weight. Hybrid $\mathrm{P}_{6}$ $\mathrm{X} \mathrm{P}_{7}$ possesses positive significant economic heterosis for grain yield per plant (41.67) and harvest index (14.63).

\section{References}

Abuali, A.I., Abdelmulla, A.A., Khalafalla, M.M., Idris, A.E. and Osman, A.M. 2012. Combining ability and heterosis for yield and yield components in maize (Zea mays L.). Aust. J. Basic and Appl. Sci., 6(10): 36-41.

Ali Asif, Hidayatur Rahman, Shah Liaqat, Shah Kashif Ali, Rehman Shamsur. 2014. Heterosis for grain yield and its attributing components in maize variety Azam using line $x$ tester analysis method. Academia J. Agri. Res., 2(11): 225-230.

Amanullah, Jehan, S., Mansoor, M. and Khan, M.A. 2011. Heterosis studies in diallel crosses of maize. Sarhad J. Agric., 27(2).

Amiruzzaman, M., Islam, M.A., Lutful Hasan; Monjurul Kadir and Rohman, M.M. 2013. Heterosis and combining ability in a diallel among elite inbred lines of maize (Zea mays L.) Emirates J. Food and Agri., 25(2): 132-137.

Appunu, C., Satyanarayana, E. and Rao, T.N. 2007. Heterosis for grain yield and its components in maize (Zea mays L.). $J$. Res. ANGRAU, 35(1): 124-126.

Avinashe, H.A., Jaiwar, S.S., Girase, V.K., Rawool, S.A., Khanorkar, S.M. 2013. Assessment of heterosis and combining ability for biochemical components in crosses among high quality protein maize (Zea mays L.). J. Soils and Crops, 23(1): 176-184.

Briggle, L.W. 1963. Heterosis in wheat. A review. Crop Sci., 3: 407-412.
Dhairyashil, M.L., Shahi, J.P., Prabhat Kumar and Amita Sharma. 2013. Estimation of heterosis for yield and yield attributing traits in diallel crosses of maize. Trends in Biosci., 6(6): 719-722.

Dubey, R.B., Joshi, V.N. and Verma, M. 2009. Heterosis for nutritional quality and yield in conventional and nonconventional hybrids of maize (Zea mays L.) Indian J. Genetics, 69(2).

East, E.M. 1908. Inbreeding in corn. Rept. Corn. Agric. Expt. Stat., pp. 419-428.

Fonesca, S. and Patterson, F. 1968. Hybrid vigour in seven parent diallel crosses in common winter wheat. Crop Sci., 8: 8588.

Gautam, S.R., Ojha, B.R., Ghimire, S.K. and Gurung, D.B. 2013. Short communication: Heterosis and combining ability of Nepalese yellow maize (Zea mays L.). Agronomy $J$. Nepal (Agron JN), Vol. 3.

Gissa, D.W., Zelleke, H., Labuchange, M.T. Hussien, T. and Singh, $H$. 2007.Heterosis and combining ability for grain yield and its components in selected maize inbred lines. South African J. Plant and Soil, 24(3): 133137.

Izhar, T. and Chakraborty M. 2013. Combining ability and heterosis for grain yield and its components in maize (Zea mays L.) in breds over environments. African J. Agri. Res., 8(25): 3276-3280.

Jampatong, S., Ngean, M.T., Balla, C., Boonrumpun, P., Mekarun, A., Jompuk, C. and Kaveeta, R. 2010. Evaluation of improved maize populations and their diallel crosses for yield. Kasetsart $J$. Nat. Sci., 44: 523-528.

Kage, U.K., Wali, M.C., Deepa, M., Natikar, P. and Gangashetty, P. 2013. Gene action and heterosis study in hybrids derived from new inbred lines in maize (Zea mays L.). Mol. Plant Breeding, 
4(18): 146-149.

Khan Rumana, Dubey, R.B. Vadodariya, G.D. and Patel, A.I. 2014. Heterosis for quantitative and quality traits in maize (Zea mays L.)Trends in Biosci., 7(3): 425-428.

Kulmi, G.K., Nagda, A.K. and Vyas, M.C. 1993. Expression of heterosis for grain yield and its components in newly developed maize. Acta. Ecol., 15: 106109.

Kumar Praveen, G., Prashanth, Y., Reddy, S.N., Kumar, S.S. and Rao, P.V. 2014. Heterosis for grain yield and its component traits in maize (Zea mays L.). Int. J. Pure and Appl. Biosci., 2(1): 106-111.

Netravati, kumar Shanta, Sateesh, G., A. MalkannavarLaxman, Gangashetty, P. 2013.Heterosis breeding for maturity, yield and quality characters in maize (Zea mays L.). Molecular Plant Breeding, 44-49.

Ofori, A.P., Ofori, K., Obeng-Antwi, K., Tengan, K.M.L., Badu-Apraku, B. 2015. Combining ability and heterosis estimate of extra-early quality protein maize (QPM) single cross hybrids. $J$. Plant Breeding and Crop Sci., Vol. 7(4): 87-93.

Raghu, B. Suresh, J. Geetha, A. Saidaiah, P. and Kumar, S.S. 2012. Heterosis for grain yield and its component traits in maize (Zea mays (L). J. Res. ANGRAU, 40(1): 83-90.

Ruswandi, D. Supriatna, J. Makkulawu, A.T. Waluyo, B. Marta, H. Suryadi, E. and Ruswandi, S. 2015. Determination of combining ability and heterosis of grain yield components for maize mutants based on linextester analysis. Asian J. Crop Sci., 7: 19-33.

Shull, G.H. 1908. What is heterosis. Genetics, 33: 439-446.

Silva, V.Q.R., Amaral, J.A.T., Gonçalves, L.S.A., Freitas, J.S.P., Candido, L.S., Vittorazzi, C., Moterle, L.M., Vieira, R.A. and Scapim, C.A. 2011. Heterotic parameterizations of crosses between tropical and temperate lines of popcorn. Acta Scientiarum, Agronomy, Maringa, 33(2): 243-249.

\section{How to cite this article:}

Meenakshi Dhoot, R.B. Dubey, K. D. Ameta, Rupal Dhoot, Ramesh Kumar and Varun Kumar Badaya. 2017. Estimation of Heterosis for Grain Yield and Architectural Traits in Yellow Seeded Maize (Zea mays L.). Int.J.Curr.Microbiol.App.Sci. 6(7): 4536-4542. doi: https://doi.org/10.20546/ijcmas.2017.607.473 